Article

\title{
Comparison of Chicken Immune Responses to Immunization with Vaccine La Sota or ZG1999HDS Strain of Newcastle Disease Virus
}

\author{
Gordana Nedeljković ${ }^{1, *}$, Hrvoje Mazija ${ }^{2}$, Željko Cvetić $^{3} \mathbb{D}$, Mladen Jergović $^{4}$, Krešo Bendelja ${ }^{3}$ \\ and Željko Gottstein ${ }^{5, *}$
}

Citation: Nedeljković, G.; Mazija, H.; Cvetić, Ž.; Jergović, M.; Bendelja, K.; Gottstein, Ž. Comparison of Chicken Immune Responses to Immunization with Vaccine La Sota or ZG1999HDS Strain of Newcastle Disease Virus. Life 2022, 12, 72. https: / / doi.org/ $10.3390 /$ life12010072

Academic Editor: Eric R. May

Received: 23 October 2021

Accepted: 25 December 2021

Published: 5 January 2022

Publisher's Note: MDPI stays neutral with regard to jurisdictional claims in published maps and institutional affiliations.

Copyright: (C) 2022 by the authors. Licensee MDPI, Basel, Switzerland. This article is an open access article distributed under the terms and conditions of the Creative Commons Attribution (CC BY) license (https:// creativecommons.org/licenses/by/ $4.0 /)$.
1 Veterinary and Food Safety Directorate General, Ministry of Agriculture, 10000 Zagreb, Croatia 2 Faculty of Veterinary Medicine, University of Zagreb, 10000 Zagreb, Croatia; mazija@vef.unizg.hr 3 Laboratory of Immunology, Centre for Research and Knowledge Transfer in Biotechnology, University of Zagreb, 10000 Zagreb, Croatia; zeljko.cvetic@unizg.hr (Ž.C.); kreso.bendelja@unizg.hr (K.B.)

4 Department of Immunobiology, The University of Arizona College of Medicine, Tucson, AZ 85719, USA; mjergovic@email.arizona.edu

5 Department of Poultry Diseases with Clinic, Faculty of Veterinary Medicine, University of Zagreb, 10000 Zagreb, Croatia

* Correspondence: gordana.nedeljkovic@mps.hr (G.N.); gottstei@vef.unizg.hr (Ž.G.)

\begin{abstract}
Newcastle disease (ND) is a highly contagious avian disease. Global control of ND is mainly based on vaccination of poultry; however, reported outbreaks of ND in vaccinated flocks indicate a constant need to re-evaluate the existing vaccines and a development of the new ones. In this study, 4-week-old male chickens of the layer commercial hybrid were immunized oculonasally with a commercial NDV live La Sota vaccine (LS group), a suspension of lyophilized NDV strain ZG1999HDS (ZG group), or saline (Control (K) group). Antibody response was determined by haemagglutination inhibition (HI) assay. Cell-mediated immunity (CMI) was characterized by immunophenotyping of leukocyte's and T-lymphocyte's subpopulations (flow cytometry). Applied NDV strains did not cause any adverse reaction in treated chickens. Both strains induced the significantly higher $\mathrm{HI}$ antibody response in comparison to the control group, and overall antibody titer was higher in ZG group than in LS group. CMI, manifested as a higher proliferation of B- and T-helper cells, yielded better results in the ZG groups than in the LS group. Based on the obtained results, we conclude that the strain ZG1999HDS is immunogenic and is a suitable candidate for further research and development of poultry vaccines.
\end{abstract}

Keywords: Newcastle disease; ZG1999HDS strain; chicken; immunization; antibody response; cell-mediated immunity

\section{Introduction}

Newcastle disease (ND) is, along with avian influenza, the most significant disease of poultry, posing an enormous economic burden for the global poultry industry. ND is caused by Avian orthoavulavirus-1 (AoAvV-1), historically known as Newcastle disease virus (NDV) [1], a member of the order Mononegavirales, family Paramyxoviridae, and genus Orthoavulavirus [2]. Depending on the species, age, and immunity status of the host and the strain of AoAvV-1, the clinical manifestation of ND varies, from unapparent infection to peracute infection with $100 \%$ mortality [3].

Global control of ND is, in addition to non-specific measures of good management practice, sanitation, and biosecurity, often based on specific immunoprophylaxis, i.e., vaccination. For this purpose, live vaccines containing apatogenic, lentogenic, or asymptomatic intestinal NDV strains, or inactivated vaccines are used [3-5]. Although currently available commercial vaccines prevent the morbidity and mortality of ND, they are unable to prevent infection with, replication, and shedding of virulent NDV strains [6-8]. Furthermore, 
prevalent contemporary circulating velogenic NDV strains are viscerotropic in nature, which makes widely used commercial vaccines based on pneumotropic strains inadequate to protect animals. This is evidenced by the outbreaks of ND in vaccinated flocks with great economic losses, e.g., Egypt in 2005, and more recently in India in 2015-2016 [9]. Moreover, due to the lentogenic or apatogenic nature of vaccine strain, the vaccine failure can be attributed to the predominant use of vaccines of genotype (gt) 1 (VG/GA, I-2) or gt 2 (LaSota, Hitchner B1), which are genetically heterologous to predominantly circulating virulent strains of gt 7 .

Haemagglutination inhibition (HI) assay or enzyme-linked immunosorbent assay (ELISA) are commonly used 3 to 4 weeks post vaccination for assessment of the immune status of animal or flock [10-13]. Antibodies appear in serum and mucosal membranes 4 to 10 days post immunization (dpi) [13] and reach peak levels at two to three weeks p.i. $[12,14]$.

In addition to the development of antibodies against NDV, cell-mediated immunity (CMI) plays an important role in protection against ND. It can be detected as early as two to three dpi or after field infection. CMI can be characterized by immunophenotyping, i.e., determination of the total leukocytes number and individual subpopulations of leukocytes (monocytes, T- and B-cells) in the peripheral blood (i.e., peripheral blood mononuclear cells, PBMCs) $[15,16]$, but also by in vitro tests of their functional capacity.

Flow cytometry is an objective analytical method that allows for qualitative and quantitative determination of biological and phenotypic characteristics of cells. Immunophenotyping uses monoclonal antibodies specific for distinctive antigens present on cells, i.e., cluster of differentiation (CD), and could be applied for identification and characterization of different immune cell subpopulations. Thus, CMI can be measured by the proliferation of lymphocytes (i.e., rise in number) and identification of alternations in lymphocyte subpopulations in peripheral blood.

ZG1999HDS strain of NDV was isolated from an outbreak in July of 1999 at a broiler farm. Previous studies on the NDV strain ZG1999HDS confirmed immunogenicity $[17,18]$ lentogenic nature [19-21], and cytolytic (oncolytic) activity in cell culture [22].

In this study, ZG1999HDS strain was further assessed for immunogenic properties, in comparison to a commercially available vaccine of La Sota strain. The comparison between the extent of CMI induction alongside the antibody response elicited by ZG1999HDS strain and the ones elicited by La Sota vaccine strain provided means for evaluation of ZG1999HDS strain as a prospective candidate for further research and vaccine development.

\section{Materials and Methods}

\subsection{Trial Animals}

The study animals included a total of 150 male chickens of the commercial layer hybrid TETRA-SL LL ("long life") (Bábolna Tetra Ltd., Bábolna, Hungary). One-day-old chickens were obtained from the Valipile hatchery (Sesvetski Kraljevec, Croatia) and moved into the experimental establishment at the Department for Poultry Diseases with Clinic, Faculty of Veterinary Medicine, Zagreb. Chickens were placed in cages with ad libitum supply of water and feed (commercial feed mixture for the respective poultry category). Chickens were kept in a single room until the onset of the trial on the 28th day; meanwhile, the weaning of maternally-derived antibodies (MDA) specific for NDV was determined in the randomly selected 10 chickens in weekly intervals. After the MDA weaning, 28-days-old chickens were divided into three groups (ZG, LS, and K) with 50 chicks in each and moved to cages in separate rooms.

During the trial, the overall health status of the chickens was monitored by the inspection during daily handling, feeding, and cleaning, and, if necessary, by other methods of clinical examination. The microclimatic housing conditions during the study were set in accordance with the hybrid manufacturer's instructions. 
All the required permits for performing experiments on animals were obtained prior to the onset of the trial from the relevant competent authorities. For the purpose of animal sacrifice, the $80 \% \mathrm{CO}_{2}$ mixture was used in compliance with all prescribed measures for the protection of animals in the experiment.

\subsection{Viral Preparations}

NDV strain ZG1999HDS was isolated from the outbreak in July of 1999 at a broiler farm in northwest part of Croatia. The outbreak took the toll of $77 \%$ mortality of the affected flock over the 17 days. Initially, the existence of viral or bacterial co infection, in addition to unfavorable environmental conditions, was considered as a cause of established mortality. In addition, negative serology findings at the time strongly suggested that the broiler flock was not vaccinated against infectious bronchitis, infectious bursal disease, or Newcastle Disease. Bacteriology further excluded salmonellosis, and feed mixture fed to chickens did not contain mycotoxins T-2 or DAS.

The virus was isolated on chicken embryos from the lung tissue, but not the brain, of broiler chickens that died at the age of 28 days, thus suggesting it is pneumotropic in nature. NDV was further confirmed, and avian influenza virus was excluded in neutralization test with respective hyperimmune sera. Initial pathogenicity parameters were mean death time of 9-10 days old chicken embryos (MDT) $>120 \mathrm{~h}$ (5-6 days) and hemagglutination (HA) titer of 1:64 $\left(1: 2^{6}\right)$. Passage on chicken SPF embryos resulted in viral allantoic fluid (VAF) that was lyophilized (i.e., freeze-dried). The determined HA titer for VAF used in the study was 1:256 $\left(1: 2^{8}\right)$. Current HA titer of 1:2048 suggests non-avian origin of virus and points to pigs being kept at the same holding of outbreak as the possible source of virus.

For comparison, we have used commercial vaccine against ND (Pestikal ${ }^{\circledR}$ La Sota SPF, Genera, Rakov potok, Croatia). Based on the data provided by the manufacturer [23], the values of pathogenicity indices were as follows: ICPI $=0.18$, IVPI $=0.0$, and MDT $>103 \mathrm{~h}$. Since the acquisition of Genera company, the vaccine seed virus is currently commercially available under the name Avishield ${ }^{\circledR}$ ND (Dechra, UK).

Both NDV strains belong to Class II and genotype II. Deduced amino acid sequence of the F0 cleavage site for both strains was ${ }^{112}$ GRQGR $\uparrow L^{117}$, a motif corresponding to lentogenic strains. However, the nucleotide identity, compared to variable region of $\mathrm{F}$ gene, was $95.9 \%$ between the two strains (unpublished data).

\subsection{Animal Procedures}

Immunization of chickens in the trial groups was performed using a La Sota vaccine at a dose $>10^{6.0-7.0} \mathrm{EID}_{50}$ / chick (LS group) or by suspension of a lyophilized VAF containing strain ZG1999HDS of NDV at a dose of $\sim 10^{6.5} \mathrm{EID}_{50} /$ chick (ZG group). The VAF and the vaccine were dissolved in sterile saline immediately prior to use. Virus preparations were applied oculonasally, a drop of $0.02 \mathrm{~mL}$ in the left eye and a drop of $0.02 \mathrm{~mL}$ in the left nostril, in an attempt to mimic the natural route of infection. Chickens in the control group (K group) were treated in the same way with the same amount of sterile saline.

Sampling of animals was performed on five randomly selected chickens per group.

Blood collection from jugular vein was performed immediately before animal sacrifice for the collection of spleen samples (not shown here):

(1) for hematology differentiation (data not shown here) and flow cytometry: with the addition of anticoagulant (Heparin, PLIVA d. d., Zagreb, Croatia) in time intervals prior to immunization (0), 3, 5, 7 and $14 \mathrm{dpi}$. Samples for flow cytometry were analyzed immediately after the blood collection.

(2) for the HI assay (10 samples/group = from randomly selected 5 chickens to be sacrificed and additional 5 chickens that were returned to the cages): without anticoagulant at time intervals 0 (before immunization), 7, and $14 \mathrm{dpi}$. Sera were separated from the whole blood and stored at $-20^{\circ} \mathrm{C}$ until analysis. 


\subsection{Laboratory Procedures}

2.4.1. Determination of Humoral Immunity by Haemagglutination Inhibition (HI) Assay

$\mathrm{HI}$ assay initially served to monitor the weaning of maternally derived antibodies (MDA) for NDV and thus assess the risk of MDA interference with viruses used to immunize chickens.

During the trial, the adaptive antibody immune response was determined by NDVspecific HI antibody titer in sera. The HI assay was performed in 96-well U-bottom microtiter plates by the standard beta procedure [24], as prescribed in the standard operating procedure (SOP) of reference laboratories [25], with a modification that the VG/GA vaccine strain (Avinew, Merial, Lyon, France) was used as an antigen.

2.4.2. Determination of Cell-Mediated Immunity by Differentiation of the Total Number of Chicken Leukocytes and Their Subpopulations in Flow Cytometry

The procedure of leukocyte isolation and flow cytometry was performed at the Department for Cellular Immunity, Institute of Immunology in Zagreb.

Leukocytes (i.e., mononuclear cells in peripheral blood of chickens, chPBMCs) were isolated from heparinized whole blood of chicken by modified ficoll-density gradient procedure, as previously described [26]. In short, heparinized chicken whole-blood samples were divided into two tubes (polystyrene, $4 \mathrm{~mL}$, BD Biosciences) with $1 \mathrm{~mL}$ in each tube and diluted 1:1 with phosphate-buffered saline (PBS, $\mathrm{pH}=7.2-7.4$, Institute of Immunology, Zagreb, Croatia). Modification of extraction method wasin additional treatment of heparinized blood with 3\% dextran T-500 (GE Healthcare Bio-Science, Uppsala, Sweden) prior to the treatment with ficoll (Histopaque ${ }^{\circledR}-1077$, Sigma-Aldrich Chemie, Steinheim, Germany).

Cell staining and immunophenotyping were performed as previously described [26]. In short, the concentration of cells was adjusted to 250,000 cells $/ \mathrm{mL}$ in two separate $4 \mathrm{~mL}$ tubes designated as L- and T-tubes. Cells in each tube were stained with different mouse monoclonal antibodies (MAbs) for chicken leukocyte surface antigens, i.e., CDs (SouthernBiotech, Birmingham, AL, USA), conjugated with fluorescent dyes (Table 1), as set for T- and L-panel (see below). Unlabeled (UNLB) mouse monoclonal antibody for chicken $\gamma \delta$ - TCR surface marker was stained with secondary antibodies for murine IgG antibodies from Zenon ${ }^{\circledR}$ Mouse IgG Labelling Kit Alexa Fluor 647 (Molecular Probe, Eugene, OR, USA). The minimum number of monoclonal antibodies to be added was previously determined by titration.

Table 1. Monoclonal mouse-antichicken antibodies (SouthernBiotech, Birmingham, AL, USA), used for multicoloured immunophenotyping in flow cytometry.

\begin{tabular}{|c|c|c|c|c|}
\hline $\begin{array}{c}\text { Leucocyte } \\
\text { Marker (CD) }\end{array}$ & Clone & $\begin{array}{l}\text { Fluorescent } \\
\text { Dye }\end{array}$ & Isotype & $\begin{array}{c}\text { Cell Population with } \\
\text { Marker }\end{array}$ \\
\hline CD45 & LT-40 & $\mathrm{APC}$ & Mouse $\operatorname{IgM}_{\kappa}$ & All leucocytes \\
\hline $\mathrm{Mo} / \mathrm{Mf}$ & KUL-01 & R-PE & Mouse $\operatorname{IgG} 1_{\kappa}$ & $\begin{array}{l}\text { Macrophages and } \\
\text { monocytes }\end{array}$ \\
\hline $\mathrm{Bu}-1$ & AV 20 & FITC & Mouse $\operatorname{IgG} 1_{K}$ & B-cells, Bursal cells \\
\hline CD3 & CT-3 & SPRD & Mouse $\operatorname{IgG} 1_{\kappa}$ & $\mathrm{T}$ cells \\
\hline CD4 & CT-4 & R-PE & Mouse $\operatorname{IgG} 1_{\kappa}$ & T helper (Th) cells \\
\hline $\mathrm{CD} 8 \alpha$ & EP-72 & FITC & Mouse IgG2 $b_{K}$ & T cytotoxic $(\mathrm{Tc})$ cells \\
\hline$\gamma \delta \mathrm{TCR}$ & TCR 1 & UNLB(APC) & Mouse $g G 1_{k}$ & $\begin{array}{l}\mathrm{T} \text { cells with } \gamma \delta \text { surface } \\
\text { receptor }\end{array}$ \\
\hline
\end{tabular}

The following two MAbs panels were used for multicolor labeling of chPBMCs:

Leukocyte panel (L-panel): MAbs -CD45-APC, -Mo/mf-R-PE, Bu-1-FITC CD3- SPRD; and T-cell panel (T-panel): MAbs -CD3- SPRD, -CD8 $\alpha$-FITC, -CD4-R-PE, and - $\gamma \delta T C R$ (TCR1)-UNLB + secondary anti-mouse Alexa Fluor 647 (APC).

Labelled cells were fixed with fixation buffer (Institute of Immunology, Zagreb, Croatia; composition: 2\% formaldehyde in Dulbecco's phosphate buffer (DPBS)) prior to the 
acquisition of at least 20,000 events, with size and granularity matching mononuclear cells i.e., leucocytes for L panel or lymphocytes for T-panel, on LSRII flow cytometer (Becton Dickinson, Mountain View, CA, USA).

Multiparametric data analysis to determine the frequency of individual subpopulations of leukocytes and T-cell was performed using FlowJo software (Version 7.6.5, Tree Star, Inc., Ashland, OR, USA). The gating strategies specific to L-panel and T-panel are shown in Figures S1 and S2 in Supplementary Materials.

\subsection{Statistical Data Analysis}

The results were analyzed with STATISTICA 12 (StatSoft Inc., OK, USA, 2013). Basic data analysis used the methods of descriptive statistics. The normality of the data distribution was verified by the Kolmogorov-Smirnov test. Given the normality of the distribution of results, the differences between the experimental and control groups were analyzed using the one-way ANOVA or Kruskal-Wallis method.

\section{Results}

\subsection{Overall Animal Health in the Experiment}

The health status of the chickens during the trial was monitored daily by inspection during routine animal handling, feeding, and cleaning. No adverse reactions or death of the chickens in connection to the applied viruses were observed during the entire trial.

\subsection{Humoral Immunity}

\subsubsection{Weaning of MDA}

Prior to the onset of the trial, $\mathrm{HI}$ assay was used to monitor the weaning of NDVspecific MDA in chickens' sera. The mean HI titer of MDA specific for NDV gradually decreased in chicken sera in weekly intervals, as seen in Figure 1. The HI titer of MDA reached values below the protective level on day 28th $(\mathrm{HI}$ titer $=0.4 \pm 0.7)$.

\section{Weaning of MDA}

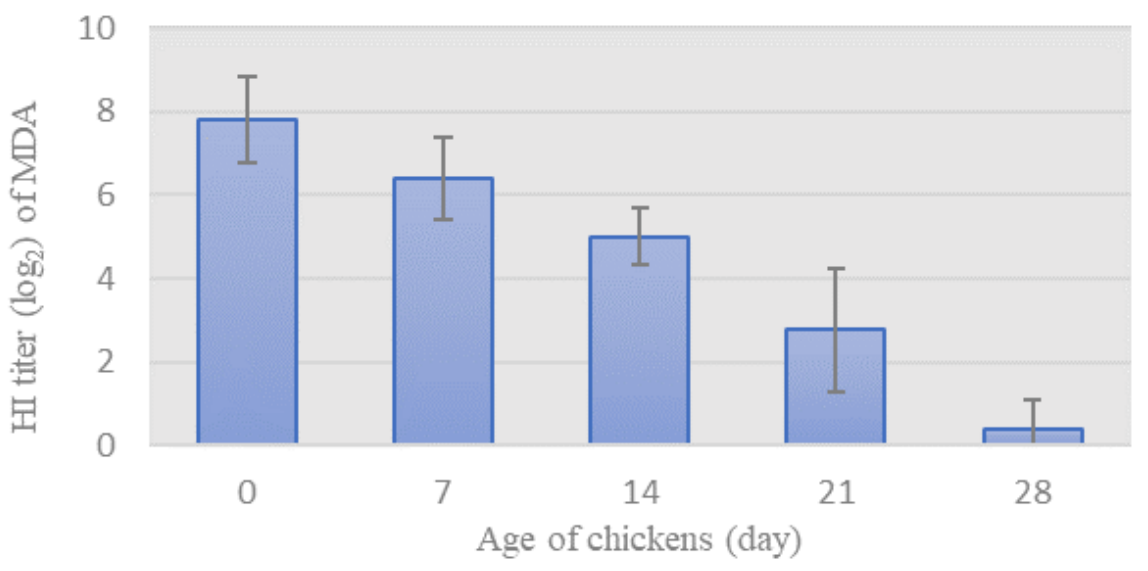

Figure 1. Weaning of MDA, as determined weekly by $\mathrm{HI}$ titer (Mean $\pm \mathrm{SD}$ ).

\subsubsection{Acquired HI Antibodies}

The HI titer of acquired specific antibodies after immunization with tested NDV strains was determined by HI assay. The results of HI titers are presented in Figure 2 and show that the applied viral preparations stimulated the development of specific antibodies in chickens in both trial groups. The increase in antibody titer was statistically significant $(p<0.05)$ in both groups of immunized chickens in comparison to the control group on $7 \mathrm{dpi}$ and $14 \mathrm{dpi}$, and, simultaneously, the titer of NDV-specific antibodies was higher in the $\mathrm{ZG}$ group compared to the LS group. 


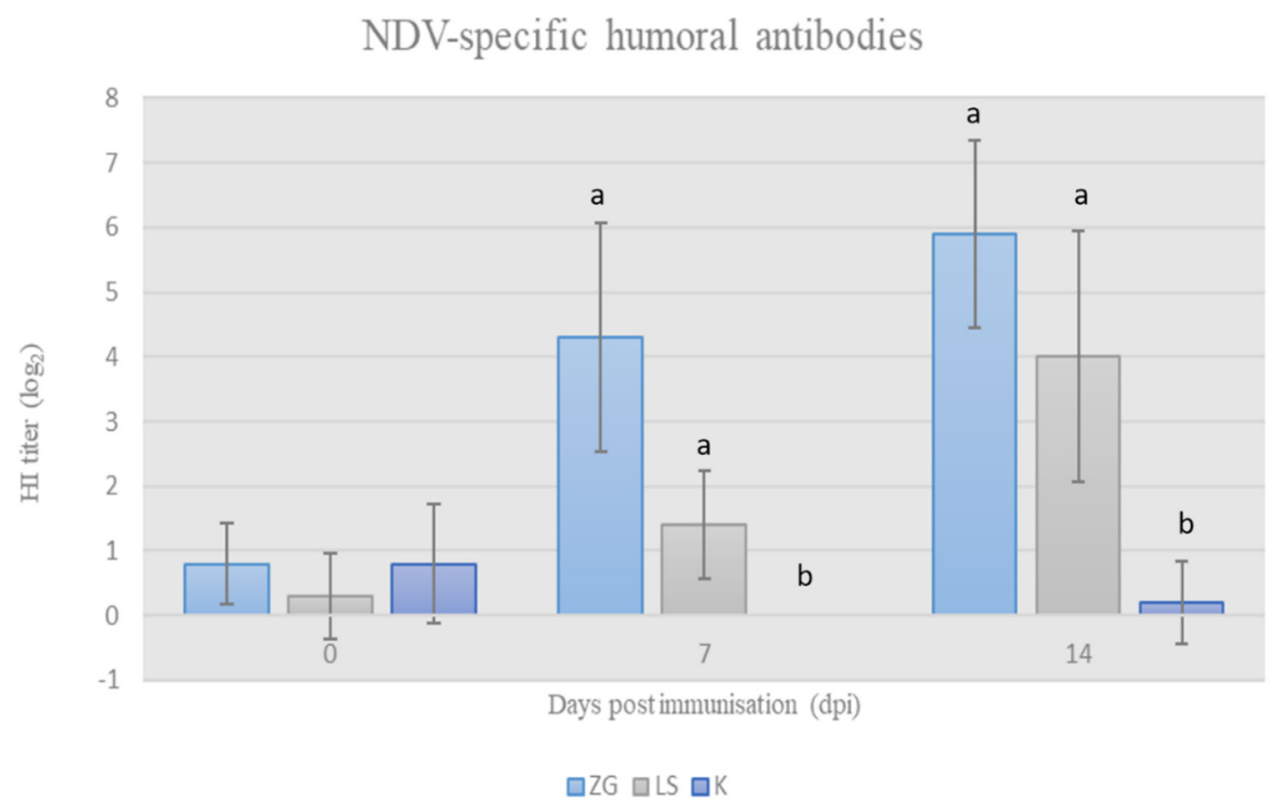

Figure 2. NDV-specific $\mathrm{HI}$ antibody titer in chicken sera at weekly intervals following immunisation at 28-days of age (mean $\pm \mathrm{SD})$. Statistically significant difference $(p<0.05)$ among the groups is designated with different letters $(a, b)$.

\subsection{Cell-Mediated Immunity}

3.3.1. Immunophenotyping of Chicken PBMCs

Leukocyte-Panel (L-Panel)

Quantitative relationships of chicken PBMC subpopulations (monocytes, B- and Tcells) were presented as a relative ratio, i.e., percentage (\%) of these populations in the chPBMCs $\left(\mathrm{CD}^{+} 5^{+}\right.$cells $\left.=100 \%\right)$. The results of immunophenotyping of chicken PBMCs labeled according to leukocyte panel (L-panel) are shown in Figure 3.

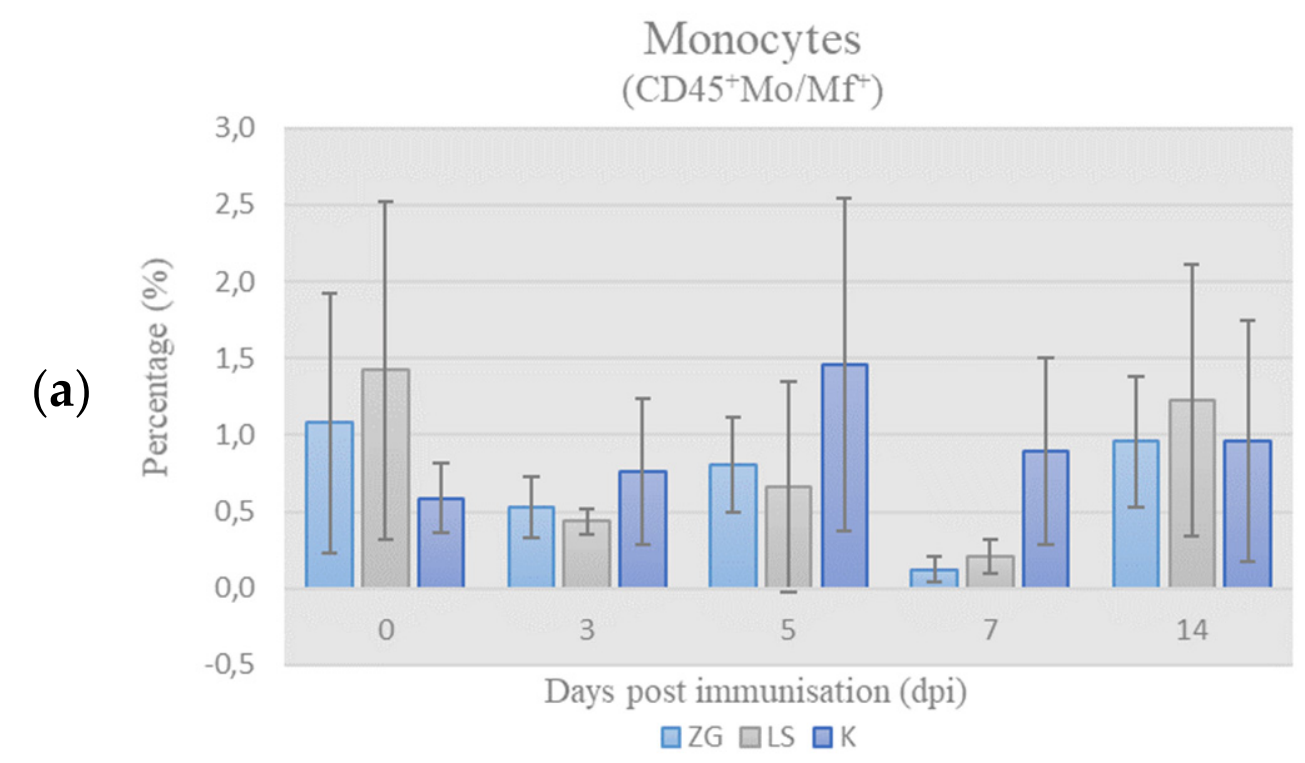

Figure 3. Cont. 
B cells

$\left(\mathrm{CD} 45^{+} \mathrm{Bu} 1^{+}\right)$

(b)
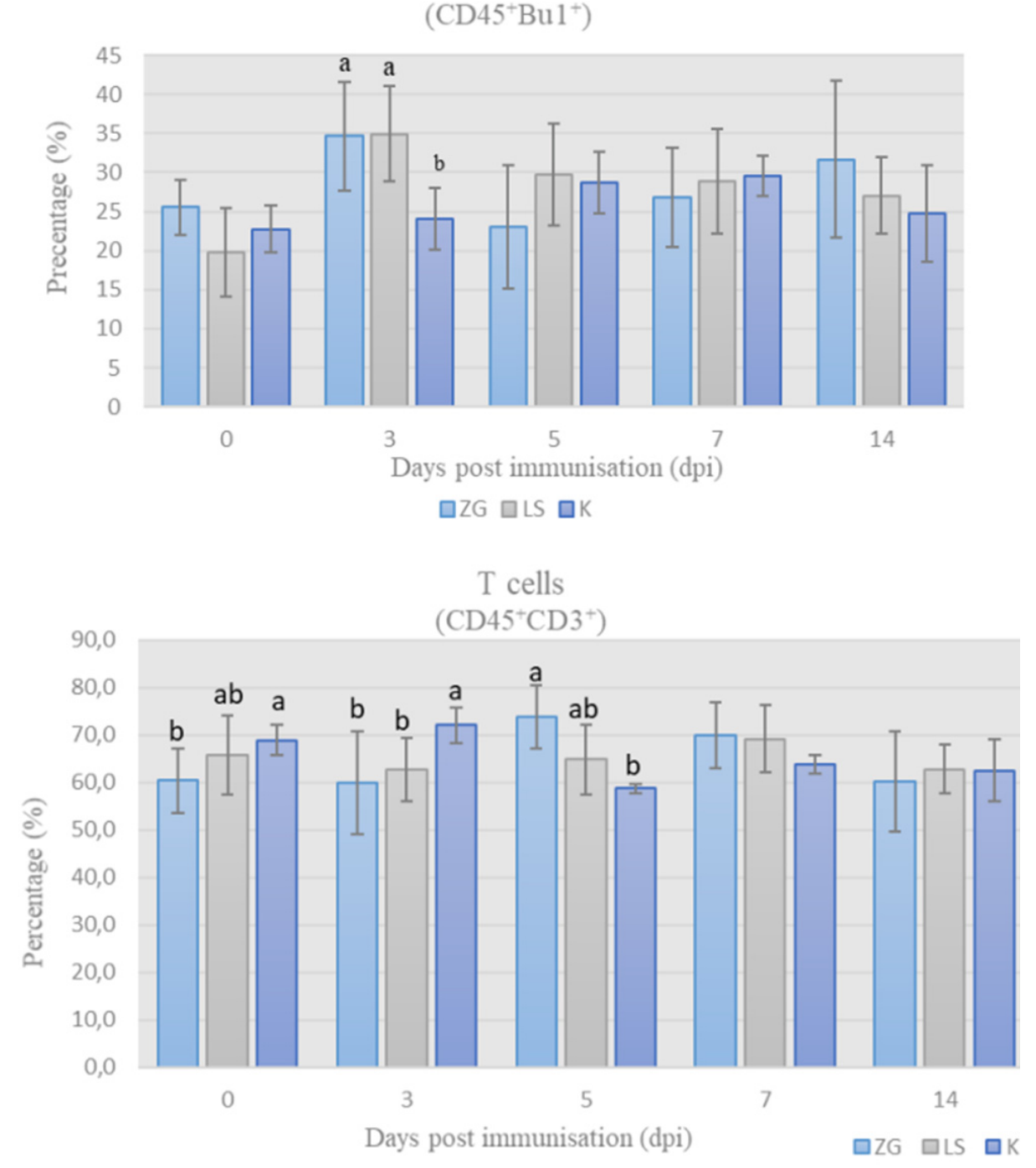

Figure 3. Results of immunophenotyping in L-panel: the percentage (\%) of monocytes (a), B cells (b), and T cells (c) in chicken PBMCs on the day of sampling (mean $\pm \mathrm{SD}$ ). Statistically significant difference $(p<0.05)$ among the groups is designated with different letters $(a, b$, and ab).

Monocytes. The results of the frequency of monocytes $\left(\mathrm{CD} 45^{+} \mathrm{Mo} / \mathrm{Mf}^{+}\right)$in chPBMCs are shown in Figure 3a. The values in all groups were below the physiological range, and no significant differences were found during the trial.

Lymphocytes' subpopulations, B- \& T-cells. The results of B-cells' $\left(\mathrm{CD} 45^{+} \mathrm{Bu}-1^{+}\right)$and T-cells $\left(\mathrm{CD} 5^{+} \mathrm{CD}^{+}\right)$frequency among chPBMCs during trial are shown in Figure $3 \mathrm{~b}, \mathrm{c}$, respectively. By $3 \mathrm{dpi}$, the frequency of B-cells increased and was significantly higher, whereas frequency of the T-cells decreased and was significantly lower in both immunized groups compared to the control group. On $5 \mathrm{dpi}$, frequency of B-cells decreased, especially in the ZG group, while in the LS group it was still higher than in controls. At the same time frequency, T-cells increased and were significantly higher in ZG group in comparison to LS group and in LS group when compared to K group. Despite the increase in frequency of B-cells by the 7th dpi, the frequency in immunized groups were lower than in control, while the reverse was found for T-cells. At the end of the experiment on day 14, the frequency of Bcells was highest in the ZG, lower in LS, and lowest in control group, but without significant differences. Simultaneously, frequency of T-cells decreased in immunized groups and was lower in ZG group and slightly higher in LS group than in control. 
T-Lymphocytes' Panel (T-Panel)

Quantitative relationships of T-cell subpopualtions $\left(\gamma \delta \mathrm{TCR}^{+} \mathrm{T}\right.$-cells and $\alpha \beta \mathrm{TCR}^{+} \mathrm{T}$ cells, and helper $\left(\mathrm{CD}^{+}\right)$and cytotoxic $\left(\mathrm{CD}^{+}\right) \mathrm{T}$-cells, $\left.\mathrm{CTL}\right)$ in the peripheral blood of chickens were shown as the relative frequency (\%) of these populations in total T-cells $\left(\mathrm{CD}^{+}\right.$cells $\left.=100\right)$. For this purpose, chPBMCs were stained with the cocktail of Mabs in T-panel, and results of flow cytometry analysis are presented in Figure 4. The results for $5 \mathrm{dpi}$ are not presented due to staining failure. Gating strategy is presented in Figure S2 in Supplementary Materials.
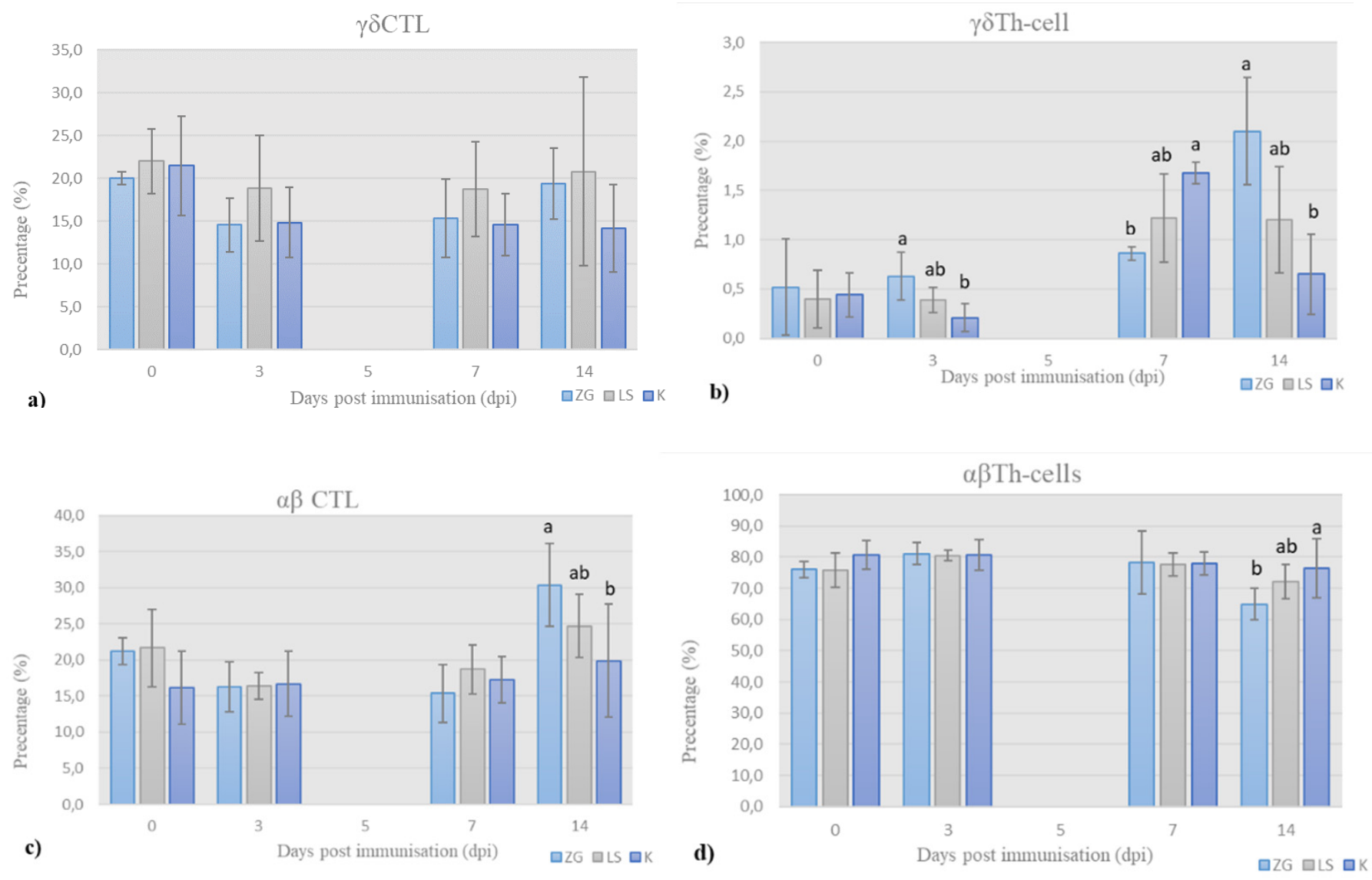

Figure 4. Results of immunophenotyping in T-panel: the frequency (\%) of (a) $\gamma \delta$ cytotoxic T-cells (CTL), (b) $\gamma \delta$ helper T-cells (Th-cells), (c) $\alpha \beta$ cytotoxic T-cells (CTL), and (d) $\alpha \beta$ helper T-cells (Th-cells) in total chicken T-cells, on the day of sampling (mean \pm SD). Statistically significant difference $(p<0.05)$ among the groups is designated with different letters $(a, b$, and $a b)$.

$\gamma \delta$ cytotoxic T-cells (CTL). The prevalence of $\gamma \delta$ cytotoxic T-cells, i.e., CTL $\left(\mathrm{CD} 3^{+} \mathrm{TCR} 1^{+}\right.$ $\left.\mathrm{CD}^{+}\right)$, is shown in Figure 4a. Initial prevalence of $\gamma \delta \mathrm{CTL}$ decreased by $3 \mathrm{dpi}$ in all the groups and then increased continuously until the end of trial in both immunized groups, and more in LS group. Simultaneously, prevalence of $\gamma \delta$ CTL in control group, after initial decrease by $3 \mathrm{dpi}$, remains almost unchanged until the end of trial.

$\gamma \delta$ helper T-cells (Th-cells). The results for prevalence of $\gamma \delta$ helper Th-cells $\left(\mathrm{CD} 3^{+} \mathrm{TCR} 1^{+}\right.$ $\mathrm{CD}^{+}$) are shown in Figure $4 \mathrm{~b}$. The prevalence is at low detectable level with values ranging from 0.5 up to $2.1 \%$ across the groups. Nevertheless, significant differences were detected. In the ZG group, it increased continuously until the end of trial, when it was significantly different than in LS and K group.

On $3 \mathrm{dpi}$, the relative proportion of $\gamma \delta$ Th-cells was higher in the immunized groups than in the control group, the highest in the ZG group, and significantly different from the control group, while the LS group did not differ significantly from these groups. By $7 \mathrm{dpi}$, prevalence of $\gamma \delta$ Th-cells increased in all the groups, with the highest values in 
the control group, which was significantly higher than the immunized ZG group but not higher than the LS group. In the second week of the trial, prevalence decreased in control group, was almost unchanged in LS group, and increased in ZG group, again significantly in comparison to control.

$\alpha \beta$ Tc-lymphocytes. The prevalence of $\alpha \beta$ CTL $\left(\mathrm{CD} 3^{+} \mathrm{TCR} 1^{-} \mathrm{CD} 8^{+}\right)$is shown in Figure 4c. By the 3dpi, the frequency of $\alpha \beta$ CTL decreased in the immunized groups and was almost the same in all the all groups. By the end of 1st week, it slightly increased in all the groups. By the end of the trial, prevalence increased in both immunized groups and was significantly higher in ZG than the LS group and in LS group compared to the control.

$\alpha \beta$ Th-cells. The prevalence of $\alpha \beta$ Th-cells $\left(\mathrm{CD} 3^{+} \mathrm{TCR} 1^{-} \mathrm{CD} 4^{+}\right)$is shown in Figure $4 \mathrm{~d}$. This subpopulation was predominant in samples of all the groups. The prevalence of $\alpha \beta$ Th-cells increased in immunized groups by $3 \mathrm{dpi}$ and remained almost the same in all the groups during the first week. By the end of trial, it decreased in immunized groups, and difference was significant between control and LS group, and between LS group and ZG group.

\section{Discussion}

Newcastle disease presents a permanent threat to global poultry production, with significant economic impact. Health of animals is pivotal for successful poultry production; thus, non-specific measures and specific immunoprophylaxis, i.e., vaccination, are essential parts of poultry management programs. Vaccination is routinely used in poultry flocks of all ages and production categories. Depending on the type of production, single-dose or repeated vaccination is performed to attain the lasting immunity of birds over production period. Vaccine-induced immunity successfully protects animals from clinical disease and death but is unable to prevent infection with, or replication and shedding of, virulent field strains or challenge viruses.

Vaccination of parental flocks elicits active immune response, and the developed antibodies are transmitted to the offspring, providing adequate protection in the first weeks of life and clear out by the age of 3 to 4 weeks [13,27]. The existence of this passive immunity results in the interference of maternally derived antibodies (MDA) in the serum of chickens with the applied vaccine [27]. To avoid this, live vaccines are administered to chickens via the mucosal membrane of digestive or respiratory tract, thus primarily stimulating local immune response at the site of application and subsequently systemic response [28].

Male chickens of a commercial laying hybrid were used in this study. As anticipated, the chickens were protected with NDV-specific MDA, as indicated by the protective HI antibody titer on the first day (Figure 1). NDV-specific MDA in commercial laying hens disappear within 5 weeks and largely prevent the development of systemic immunity but not the local [27]. In order to characterize the effect of NDV strain ZG1999HDS on the immune response of immunologically naïve chickens, as well as the sequence of events at the initial outbreak, the level of MDA in chicken sera had to be below protective. Therefore, the weaning of MDA was monitored in chicken sera at weekly intervals in order to determine the appropriate time-point to start the experiment. Based on the results (Figure 1), the onset of the trial was set at 28 days when the level of detected antibodies was below protective. The preparations of NDV strain ZG1999HDS or vaccine strain La Sota were applied oculonasally to the 28-days old chickens of the experimental groups, thus imitating the natural route of infection, and saline was applied to the control group via the same route.

Live vaccines containing La Sota strain, when applied via the respiratory tract in newly hatched chickens, can cause adverse reaction manifested in form of damage to the epithelium in the trachea and the disappearance of cilia and thus create a predisposition to secondary bacterial infections [13]. However, for the entire duration of the trial we did not record any adverse reactions or deaths in any of immunized chickens. This finding could be due to the age of trial animals at the time of immunization, as by that age the immune system was fully competent to mount an adequate response. This could also be due to the 
lentogenic nature of both strains used, as confirmed by the standard in vivo pathogenicity test, and the analysis of the deduced amino acid sequence at the fusion protein (F0) cleavage site. Additionally, such a finding suggests that the significant mortality of broilers during the initial outbreak, when the ZG1999HDS strain was isolated, was unlikely caused by infection with NDV. However, as a pneumotropic agent, it could have contributed to unfavorable effect of environmental and housing conditions. This is supported by its isolation from the lungs but not the brain of the dead chickens, and further by the necropsy findings of an extensive parenchymal hemorrhage in the lungs with effusion of blood into the air sacs, which is indicative of suffocation [22].

Overall immunity, elicited by field infection or vaccination, arises through the process of coordination and interaction of different types of immune cells. Specific humoral and cell-mediated immune responses are governed by the components of innate immunity. With this in mind, we decided to further investigate the cell-mediated immune response in chickens after immunization with ZG1999HDS strain.

The results of this research further supplement previous findings on the immunogenicity of the ZG1999HDS strain. Strain ZG1999HDS strongly stimulated the development of antibodies in comparison to the vaccine La Sota strain, which was manifested by a higher $\mathrm{HI}$ antibody titer on the 7 and 14 dpi. In both immunized groups, HI antibody titers were significantly higher than in the control group (Figure 2).

Cell-mediated immunity (CMI) plays a key role in the protection against NDV, as evidenced by the protection of bursectomised (i.e., B-cell depleted) chickens [29]. The CMI to NDV can be characterized by immunophenotyping by flow cytometry, i.e., determining the frequency of effector immune cells in the blood, thymus, and spleen, and other lymphatic organs $[16,30]$. Immunophenotyping of chicken PBMCs provides good insight into the proliferation of immune cells in response to vaccination or natural infection. Thanks to the growing number of currently available monoclonal antibodies, its use increases, however, due to high costs, it remains limited mostly to research and development of vaccine [15,31].

In this study, the frequency of B-cells $\left(\mathrm{CD} 45^{+} \mathrm{Bu}-1^{+}\right)$in the population of chicken PBMCs in both immunized groups increased, reaching peak values on 3 dpi (Figure $3 b$ ). This finding suggests enhanced activation and proliferation/recruitment of B-cells, and indirect activation of the CMI [32,33], since B-cells also serve as antigen-presenting cells for Th-cells.

The frequency of T-cells followed the increase in B-cells' percentage; however, it was slightly delayed, reaching "peak" on $5 \mathrm{dpi}$ in both immunized groups and was significantly higher in ZG than in the control groups (Figure 3c). This indicates ongoing humoral immune response induced by both ZG1999HDS and La Sota strains, and is supported by the active role of Th-cells to trigger an appropriate immune response [34,35]. In particular, observed increase on $3 \mathrm{dpi}$ in $\gamma \delta$ Th-cells and B cells percentage, along with the high frequency of $\alpha \beta$ Th-cells (Figure 3a), was probably associated with higher HI titers on day 7 in immunized groups.

Contrary to Th-cells, the increase in CTL frequencies, particularly $\alpha \beta C T L$, was delayed and significantly different $14 \mathrm{dpi}$ in both immunized groups. It was established that effectors' antiviral CTL differentiation follows an initial antibody immune response and is detectable a few days later [32]. This is also the case in other viral infections, e.g., influenza A viral infection [36].

\section{Conclusions}

Based on the obtained results, it can be concluded that the immunization of chickens with ZG1999HDS strain has elicited CMI, which manifested as stronger activation of-cells than the La Sota vaccine strain and as higher frequencies of Th- cells.

Given the stimulating effect of the strain ZG1999HDS on both the antibody and cellular immune response in chickens, it is justified to consider ZG1999HDS strain for further indepth study and possible development of a vaccine for domestic poultry. This should include analysis of functional capacity of specific immune cells isolated from spleen and 
blood upon virus-specific stimulation. Finally, to confirm efficacy, a challenge infection with a virulent NDV strain should be performed to provide valuable insights into the protective level of the mounted immunity in chickens.

Supplementary Materials: The following are available online at https:/ / www.mdpi.com/article/ 10.3390/life12010072/s1, Figure S1: Gating strategy for L-panel. Figure S2: Gating strategy for T-panel.

Author Contributions: Conceptualization, G.N.; Data curation, G.N. and Ž.G.; Formal analysis, G.N., Ž.C., M.J., K.B. and Ž.G.; Funding acquisition, H.M., K.B. and Ž.G.; Investigation, G.N., Ž.C. and M.J.; Methodology, G.N., M.J., K.B. and Ž.G.; Project administration, H.M. and Ž.G.; Resources, H.M., K.B. and Ž.G.; Software, M.J.; Supervision, H.M., K.B. and Ž.G.; Validation, G.N., K.B. and Ž.G.; Visualization, G.N. and Ž.C.; Writing—original draft, G.N.; Writing—review and editing, H.M., Ž.C., M.J., K.B. and Ž.G. All authors have read and agreed to the published version of the manuscript.

Funding: The research was part of the project "Immunoprophylaxis of diseases of poultry and other birds" (grant number: 053-0531863-1858; grant holder professor Hrvoje Mazija, and as of 2011, associate professor Željko Gottstein) and PhD project of Gordana Nedeljkovic. The project was funded by the Ministry of Science and Technology (and its successors), Republic of Croatia, in the period from 2005-2013. Gordana Nedeljkovic was funded by the Ministry of Science and Sports, Republic of Croatia, during PhD and postdoctoral studies (2008-2018).

Institutional Review Board Statement: All the required permits for performing experiments on animals were obtained from the competent authorities: The Decision on approval of animal testing, Veterinary Directorate, Ministry of Agriculture, 7 February 2013; The decision of the Ethics Committee, Faculty of Veterinary Medicine in Zagreb, confirmed at the sessions of the Faculty Council on 26 April 2012, and its amendments on 16 April 2013. The issued permits and trial procedures were aligned with the Animal Protection Act (Official Gazette, No. 135/06), the Act Amending the Animal Protection Act (OG, No 37/13), the Ordinance on the Protection of Animals Used for Scientific Purposes (OG 55/13), and the Code of Ethics of the Faculty of veterinary medicine, University of Zagreb.

Informed Consent Statement: Not applicable.

Data Availability Statement: Not applicable.

Conflicts of Interest: The authors declare no conflict of interest.

\section{References}

1. Alexander, D.J. Gordon Memorial Lecture. Newcastle disease. Br. Poult. Sci. 2001, 42, 5-22. [CrossRef] [PubMed]

2. Dimitrov, K.M.; Abolnik, C.; Afonso, C.L.; Albina, E.; Bahl, J.; Berg, M.; Briand, F.-X.; Brown, I.H.; Choi, K.-S.; Chvala, I.; et al. Updated unified phylogenetic classification system and revised nomenclature for Newcastle disease virus. Infect. Genet. Evol. 2019, 74, 103917. [CrossRef]

3. Suarez, D.L.; Miller, P.J.; Koch, G.; Mundt, E.; Rautenschlein, S. Newcastle Disease, Other Avian Paramyxoviruses, and Avian Metapneumovirus Infections. In Diseases of Poultry, 14th ed.; David, E., Swayne, M.B., Catherine, M.L., Larry, R.M., Venugopal, N., David, L.S., de Wit, S., Grimes, T., Deirdre, J., Michelle, K., Eds.; Wiley-Blackwell: Hoboken, NJ, USA, 2020; pp. 109-166.

4. Peeters, B.; Koch, G. Newcastle Disease Virus (Paramyxoviridae). In Encyclopedia of Virology; Elsevier: Amsterdam, The Netherlands, 2021; pp. 648-653, ISBN 9780128096338.

5. Gallili, G.E.; Ben-Nathan, D. Newcastle disease vaccines. Biotechnol. Adv. 1998, 16, 343-366. [CrossRef]

6. Liu, R.; Chen, C.; Huang, Y.; Cheng, L.; Lu, R.; Fu, G.; Shi, S.; Chen, H.; Wan, C.; Fu, Q.; et al. Microbiological identification and analysis of waterfowl livers collected from backyard farms in Southern China. J. Vet. Med. Sci. 2018, 80, 667-671. [CrossRef] [PubMed]

7. Igwe, A.O.; Agbakwuru, I.O. Haemagglutination inhibition antibody responses of pullet and broiler chickens (Gallus gallus domesticus) to Newcastle disease virus LaSota vaccination. Sokoto J. Vet. Sci. 2019, 16, 36. [CrossRef]

8. Bello, M.B.; Yusoff, K.; Ideris, A.; Hair-Bejo, M.; Peeters, B.P.H.; Omar, A.R. Diagnostic and Vaccination Approaches for Newcastle Disease Virus in Poultry: The Current and Emerging Perspectives. BioMed Res. Int. 2018, 2018, 7278459. [CrossRef]

9. Gowthaman, V.; Ganesan, V.; Gopala Krishna Murthy, T.R.; Nair, S.; Yegavinti, N.; Saraswathy, P.V.; Suresh Kumar, G.; Udhayavel, S.; Senthilvel, K.; Subbiah, M. Molecular phylogenetics of Newcastle disease viruses isolated from vaccinated flocks during outbreaks in Southern India reveals circulation of a novel sub-genotype. Transbound. Emerg. Dis. 2019, 66, 363-372. [CrossRef]

10. Abolnik, C.; Mubamba, C.; Dautu, G.; Gummow, B. Complete Genome Sequence of a Newcastle Disease Genotype XIII Virus Isolated from Indigenous Chickens in Zambia. Genome Announc. 2017, 5, 2-3. [CrossRef]

11. Abolnik, C. History of Newcastle disease in South Africa. Onderstepoort J. Vet. Res. 2017, 84, e1-e7. [CrossRef] [PubMed] 
12. Kapczynski, D.R.; Afonso, C.L.; Miller, P.J. Immune responses of poultry to Newcastle disease virus. Dev. Comp. Immunol. 2013, 41, 447-453. [CrossRef] [PubMed]

13. Al-Garib, S.O.; Gielkens, A.L.J.; Gruys, E.; Koch, G. Review of Newcastle disease virus with particular references to immunity and vaccination. Worlds Poult. Sci. J. 2003, 59, 185-200. [CrossRef]

14. Alexander, D.J.; Senne, D.A. Newcastle Disease. In Diseases of Poultry, 12th ed.; Aly, M., Saif, A.M., Fadly, J.R., Glisson, L.R., McDougald, L.K., Nolan, D.E.S., Eds.; Iowa State University Press: Ames, IA, USA, 2008; pp. 75-116.

15. Balenović, M.; Popović, M.; Savić, V.; Kezić, D.; Vlahović, K.; Dovč, A.; Bezrok, G.; Popović, I.; Valpotić, I. Kvantitativna imunofenotipizacija T-limfocita periferne krvi kokoši nesilica. Prax. Vet. 2007, 55, 33-39.

16. Dalgaard, T.S.; Norup, L.R.; Pedersen, A.R.; Handberg, K.J.; Jørgensen, P.H.; Juul-Madsen, H.R. Flow cytometric assessment of chicken T cell-mediated immune responses after Newcastle disease virus vaccination and challenge. Vaccine 2010, 28, 4506-4514. [CrossRef]

17. Bidin, M.; Mazija, H. Immunogenicity of the field strain NDV Zg-2000 administered to the SPF chickens. In Proceedings of Pultry Days 2009; Mirta, B., Ed.; Poultry Centre: Zagreb, Croatia, 2009; pp. 241-245.

18. Cvetić, Ž.; Nedeljković, G.; Jergović, M.; Bendelja, K.; Mazija, H.; Gottstein, Ž. Immunogenicity of Newcastle disease virus strain ZG1999HDS applied oculonasally or by means of nebulization to day-old chicks. Poult. Sci. 2021, 100, 101001. [CrossRef]

19. Runjić, I. Genomic Characteristics of the Strain ZG-2000 of the Virus of Newcastle Diseas; Faculty of Science, University of Zagreb: Zagreb, Croatia, 2006.

20. Stupar, M. Evidence of Horizontal Spread of Newcastle Disease Virus Strain ZG1999HDS after iv Application in Chickens; Faculty of Veterinary Medicine, University of Zagreb: Zagreb, Croatia, 2012.

21. Nedeljković, G. (Veterinarski fakultet) Genomic Characterisation and Phylogenetic Analysis of a Newcastle Disease Virus Isolate (ZG1999HDS) from an Outbreak in 1999 in Croatia; Uppsala University: Uppsala, Sweden, 2011.

22. Mazija, H.; Gottstein, Ž.; Ivanković, S.; Čović, D. Lentogenic cytolitic strain of the Newcastle Disease Virus isolated in Croatia. In IX Symposium Poultry Days 2011 with International Participation Croatia, Šibenik, 11-14 May 2011; Balenović, M., Ed.; Poultry Centre: Zagreb, Croatia, 2011; pp. 48-58.

23. Anonymous. (Genera) Pestikal®Cjepivo Protiv Newcastleske Bolesti; Hrvatski veterinarski Institut: Rakov Potok, Croatia, 2013; Volume 10

24. Allan, W.; Gough, R. A standard haemagglutination inhibition test for Newcastle disease. (1). A comparison of macro and micro methods. Vet. Rec. 1974, 95, 120-123. [CrossRef]

25. Anonnymous. Newcastle Disease (Infection with Newcastle disease virus). In Manual of Diagnostic Tests and Vaccines for Terrestrial Animals, 8th ed.; Organisation for Animal Health: Paris, France, 2018; Volume 3, pp. 1-22.

26. Jergović, M.; Nedeljković, G.; Cvetić, Ž.; Gottstein, Ž.; Bendelja, K. Combined dextran and ficoll separation yields pure populations of chicken peripheral blood mononuclear cells-Short communicationia. Vet. Arh. 2017, 87, 623-631. [CrossRef]

27. Rauw, F.; Gardin, Y.; Palya, V.; van Borm, S.; Gonze, M.; Lemaire, S.; van den Berg, T.; Lambrecht, B. Humoral, cell-mediated and mucosal immunity induced by oculo-nasal vaccination of one-day-old SPF and conventional layer chicks with two different live Newcastle disease vaccines. Vaccine 2009, 27, 3631-3642. [CrossRef]

28. Sasipreeyajan, J.; Pohuang, T.; Sirikobkul, N. Efficacy of Different Vaccination Programs against Newcastle Disease Virus Challenge in Broiler Chickens. Thai J. Vet. Med. 2012, 42, 431-437.

29. Lambrecht, B.; Gonze, M.; Meulemans, G.; van den Berg, T.P. Assessment of the cell-mediated immune response in chickens by detection of chicken interferon-gamma in response to mitogen and recall Newcastle disease viral antigen stimulation. Avian Pathol. 2004, 33, 343-350. [CrossRef]

30. Norup, L.R.; Dalgaard, T.S.; Pedersen, A.R.; Juul-Madsen, H.R. Assessment of Newcastle disease-specific T cell proliferation in different inbred MHC chicken lines. Scand. J. Immunol. 2011, 74, 23-30. [CrossRef]

31. Kaiser, P.; Stäheli, P. Avian Cytokines and Chemokines. In Avian Immunology; Elsevier: Amsterdam, The Netherlands, 2014; pp. 189-204.

32. Tizard, I. Veterinary Immunology, 9th ed.; Tizard, I., Ed.; Elsevier Saunders: St. Louis, MO, USA, 2013 ; ISBN 9780323291699.

33. Kristeen-Teo, Y.W.; Yeap, S.K.; Tan, S.W.; Omar, A.R.; Ideris, A.; Tan, S.G.; Alitheen, N.B. The effects of different velogenic NDV infections on the chicken bursa of Fabricius. BMC Vet. Res. 2017, 13, 151. [CrossRef]

34. Degen, W.G.J.; Daal, N.V.; Rothwell, L.; Kaiser, P.; Schijns, V.E.J.C. Th1/Th2 polarization by viral and helminth infection in birds. Vet. Microbiol. 2005, 105, 163-167. [CrossRef]

35. Kaiser, P. Advances in avian immunology-prospects for disease control: A review. Avian Pathol. 2010, 39, 309-324. [CrossRef]

36. Zitzmann, C.; Kaderali, L. Mathematical Analysis of Viral Replication Dynamics and Antiviral Treatment Strategies: From Basic Models to Age-Based Multi-Scale Modeling. Front. Microbiol. 2018, 9, 1546. [CrossRef] 